\title{
DIGITAL ENTREPRENEURSHIP AND EMPOWERMENT: A CHALLENGE FOR THE EXECUTIVE SECRETARY
}

\author{
Liliane Matias de Almeida, Walkiria Aparecida Gomes de Almeida \\ and Luciana Florêncio de Almeida \\ ESPM, Brazil
}

\begin{abstract}
The aim of this article is to understand how the strategic action of entrepreneurship and the access and use of technology empower women to manage their professional career in the area of executive secretariat. The theory defines entrepreneurship as an individual's ability to seize or create opportunities, involving time and financial investment risks, but can also be considered as a strategic action of the individual in a particular activity, whether it is its own business or as a project leader. The advancement and development of technology contributes to the digital empowerment of the individual, regardless of gender, but access and use is required. To reach the objective of this research, the methodology used includes a survey through in-depth interview and questionnaire with quantitative approach. An interview was conducted with the company founder Click Secretária and the applied questionnaire obtained 128 answers. The results propose a deductive analysis for the understanding of entrepreneurship as a strategic action and the use of technology as digital empowerment in the executive secretariat area.
\end{abstract}

\section{KEYWORDS}

Empowerment, Women, Technology, Entrepreneurship, Executive Secretariat

\section{INTRODUCTION}

Over the years, different approaches have been used in studies aimed at understanding the characteristics of entrepreneurship, and we can cite risk association (Cantillon, 1975), transfer of financial resources from one sector to another (Brito and Wever, 2003), innovation (Schumpeter, 1950, p. 39), activity that sells products and services for profit (Casson, 1982) and the ability to identify opportunity and create a business while minimizing risks (Dolabela, 1999) presents as one. In addition to these approaches, entrepreneurship was a theme used by Mintzberg (2009) as a strategy used by the leader. Entrepreneurial action has access and use of technology as a strategic tool, but when analyzing the level of technology use by each gender, it is identified that women have less access than men (Sirotin \& Arkhipova, 2018). The topic, besides being discussed in the academic environment, has a performance within universities, and institutions such as SEBRAE and ENDEAVOR contribute to fostering entrepreneurship.

The access to and use of technology is an important theme when discussed in light of its contribution to empowerment. As a way of empowering, entrepreneurship as a strategic action and access and use of technology are present in the reality of the individual, regardless of gender. Weber (1991) contributes to the definition of power related to the awareness of the individual's possibilities of acting in society, and in this context, technology is a strategic tool for empowerment in entrepreneurship.

The conception of entrepreneurship is not limited to starting a new business, but its use as a management strategy tool. To corroborate entrepreneurial strategy, technology development is critical, as is access and use as part of entrepreneurial strategy. Considering the individual's participation in access to and use of technology, gender differences in the development and use of technologies in developing countries exist, as well as the objective in the use of technologies (Sirotin \& Arkhipova, 2018).

In recent decades, technology has evolved a lot and the secretarial professional has been part of that evolution. It currently develops both technical and human skills. Has a critical sense, ethical posture, ability to articulate, generalist view, proactively manages information, and acts as a manager in some companies. This 
professional is directly linked to the decision-making power of public and private companies. (Neiva \& D’Elia, 2014).

Another factor that reinforces the advances of the profession is the research done in the United States in April 1995 and published in Brazil by journalist Gilberto Dimenstein (Dimenstein, 1995). Through it we learn that the secretariat is the third fastest growing profession in the world. In first and second place we find the professions of salespeople and teachers respectively. The English newspaper "The Guardian" paid tribute to Brazil's secretarial professional in 2001 with the story "The World's Best Secretaries are Brazilian". This reaffirms the international recognition of the profession (FENASSEC, 2001).

In the past, the secretarial professional was seen as a simple performer, doing only the operative. But today, it operates in the strategic area, leads teams and uses the technological tools with great quality. With this, it is clear that the secretary is increasingly competitive in the job market. Over the last decades, it has been observed that the profession has undergone many transformations and achieved many achievements. It can be mentioned: regulatory laws, in 1985, code of ethics, in 1987, creation of the Federation of secretariat professionals, class unions throughout Brazil, from 1986, and participation in the CBO - Classificação Brasileira de Ocupações, in 2002 (Almeida, 2016).

In this sense, we also notice many changes in the area of Education. In March 2004, the Diretrizes Curriculares Nacionais were approved, through the opinion in CNE/CES 102/2004, for the Curso de Secretariado Executivo (DCN, 2004). This course aims to train bachelors with general and humanist training, with ability to articulate knowledge, critical vision and preparation for the competitive job market.

In short, the executive secretarial professional occupies a prominent place in organizations, uses technological tools, has emotional intelligence to relate to people of different profiles, uses outcome indicators and has a global mindset.

In this sense, understand as themes such as access and use of technology and action taken as a strategic tool for women's empowerment, this study answers the following question: How can access and use of technology and entrepreneurship as a strategic action can contribute with women's empowerment for career management in executive secretariat? And for that, we will use an in-depth interview and questionnaire for data collection, quantitative approach and contributions to the academic field for an area of executive secretariat.

The paper is structured in five sessions, including this introduction. A review of the literature, methodology, results and discussion and conclusion.

\section{THEORETICAL RATIONALE}

\subsection{Entrepreneurship}

The Austrian economist Joseph A. Schumpeter, in the book "Capitalism, Socialism and Democracy", published in 1942, associates the entrepreneur with economic development. According to him, the capitalist system has as its inherent characteristic, a force that he calls the process of creative destruction, based on the principle that lies in the development of new products, new methods of production and new markets; In short, it is about destroying the old to create the new. By Schumpeter's definition, the basic agent of this process of creative destruction lies in the picture of what he called an entrepreneur.

The discourse on entrepreneurship that gains space and strength in the country, now gains space within universities. SEBRAE is one of the main institutions that contributes to the entrepreneurial initiative in Brazil, offering courses, support, training and partnership with educational institutions to promote entrepreneurship. ENDEAVOR Brasil is a nonprofit organization that supports high impact entrepreneurs around the world. It is present in more than 20 countries, and with 8 offices in various regions of Brazil. Entrepreneurship is associated or disseminated by higher education institutions, which address entrepreneurship in the curriculum of their courses, as well as encourage the practice through programs within their facilities. Still about institutions, encouraging entrepreneurship, the Instituto Brasileiro de Geografia e Estatísitica (IBGE), it is an institute that provides information and data that help interpret the social entrepreneurship phenomenon.

The conception of entrepreneurship comes from the term "entrepreneur", and was first used by the Irish economist Richard Cantillon in 1975 when interpreting as the risk taker (Chaves, 2015). In the same thought, Brito and Wever (2003) point to the French economist J. B. Say with the definition of entrepreneurship in the early 20th century as the individual who transfers financial resources from one sector to another with a greater 
possibility of profitability. In the 20th century, we find a definition more focused on innovation, elaborated by Schumpeter (1950, p. 39) "the curve of economic and social stagnation through the induction of innovative activities capable of adding economic and social values". In a more recent view, Casson (1982) defines entrepreneurship as the activity that sells profitable products and services as a result, and Dolabela (1999) presents entrepreneurship as the ability to identify opportunity and create a business while minimizing risk.

Following the reasoning of definitions, Dornelas (2001) presents entrepreneurship as a free translation of entrepreneurship. Despite epistemological definitions, and all of them geared to the initiative of the individual, entrepreneurship involves risks of time and financial investment (Drucker 1993) and the ability to work with uncertainty (Knight 1972).

Entrepreneurship is present in society, and needs an individual to be implemented. In the book "Strategy Safari”, Mintzberg, Ahlstrand, and Lampel (2009) wrote and identified ten strategic business schools, one of which was conceived under the name Entrepreneurial School. For the authors, strategy formulation is in the leader who has perspective and vision. The entrepreneurial strategy is deliberate in its sense of direction and emergent in detail as it can be adapted along the way. The entrepreneurial leader's strategic thinking has a broad vision and looks beyond, thus enabling the construction of a creative context for an innovative future.

The entrepreneur, according to Schumpeter (1942), is the person with the business idea who creates new combinations and deals with changes in structures. Strategically, management has developed the entrepreneurial school, and personalized leadership, based on strategic vision, is the key to organizational success. The entrepreneurial leader is aware of opportunities, and even in an environment of uncertainty, is always contributing to the growth and differentiation of the company. Initiative is a characteristic of the leading entrepreneurial individual, the act of undertaking involves risks of time and financial investment (Drucker, 1993) and the ability to work with uncertainty (Knight, 1933).

\subsection{Technology Access and Use}

The entrepreneur, according to Schumpeter (1942), is the person with the business idea who creates new combinations and deals with changes in structures. Strategically, management has developed the entrepreneurial school, and personalized leadership, based on strategic vision, is the key to organizational success. The entrepreneurial leader is aware of opportunities, and even in an environment of uncertainty, is always contributing to the growth and differentiation of the company. Initiative is a characteristic of the leading entrepreneurial individual, the act of undertaking involves risks of time and financial investment (Drucker, 1993) and the ability to work with uncertainty (Knight, 1933).

Access to information technology is an important factor for the development of countries. Hafkin and Taggart in 2001 did research and pointed out that in developing countries women had less access to technology. However, information technology has had an impact on the behavior and life of women who, despite having a double shift, began to look for space and opportunities in the labor market, demanding equal pay, lowering the birth rate and choosing to have fewer children. or saying no to motherhood and investing more in education. At the beginning of the technology movement in developing countries, a different position was the position of secretary, but with the pursuit of women's empowerment, considering development as well as the autonomy of power for decision making (Marinho \& Gonçalves, 2016), took women to other areas of the market, including technology.

Access to information technology is an important factor for the development of countries. Hafkin and Taggart in 2001 did research and pointed out that in developing countries women had less access to technology. However, information technology has had an impact on the behavior and life of women who, despite having a double shift, began to look for space and opportunities in the labor market, demanding equal pay, lowering the birth rate and choosing to have fewer children. or saying no to motherhood and investing more in education. At the beginning of the technology movement in developing countries, a different position was the position of secretary, but with the pursuit of women's empowerment, considering development as well as the autonomy of power for decision making (Marinho \& Gonçalves, 2016)., took women to other areas of the market, including technology.

The digital enterprise is a worldwide phenomenon, in Brazil the e-commerce has a positive growth, and the models include Company-Consumer (B2C), Company-Company (B2B) and Consumer-Consumer (C2C). For Laudon and Laudon (2007), one of the advantages of the digital market is the low investment, but in relation to the traditional market, it has the following advantages: 
Table 1. Digital markets compared to traditional markets

\begin{tabular}{|c|c|c|}
\hline & Mercados Digitais & Mercados Tradicionais \\
\hline Assimetria de Informação & Assimetria reduzida & Alta assimetria \\
\hline Custos de busca & Baixos & Altos \\
\hline Custos de transação & $\begin{array}{l}\text { Baixos (às vezes } \\
\text { praticamente nenhum) }\end{array}$ & $\begin{array}{l}\text { Altos } \\
\text { deslocamento) (tempo, }\end{array}$ \\
\hline Demora no desfrute & $\begin{array}{l}\text { Alta (mais baixa no caso de } \\
\text { uma mercadoria digital) }\end{array}$ & Mais baixa: compre agora \\
\hline Custos de menu & Baixos & Altos \\
\hline $\begin{array}{l}\text { Determinação dinâmica } \\
\text { de preços }\end{array}$ & Instantânea e de baixo custo & Demorada e de alto custo \\
\hline Discriminação de preços & Instantânea e de baixo custo & Demorada e de alto custo \\
\hline Segmentação de mercado & $\begin{array}{l}\text { Baixo custo, precisão } \\
\text { moderada }\end{array}$ & Alto custo, menos precisão \\
\hline Custos de mudança & $\begin{array}{l}\text { Mais altos ou mais baixos } \\
\text { (dependendo das } \\
\text { caracteristicas do produto) }\end{array}$ & Altos \\
\hline Efeitos de rede & Fortes & Mais fracos \\
\hline Desintermediação & Mais possivel/provável & Menos possível/improvável \\
\hline
\end{tabular}

Source: Laudon, Laudon, 2007, p. 277

\subsection{Female Empowerment}

In the digital world, women had stronger networks than men, but had less decision-making and less expertise in information technology. The authors Sirotin \& Arkhipova (2018) noted difficult access to data to analyze technology use, as well as to distinguish or divide this data by gender.

The importance of analyzing issues related to women and empowerment is directly related to economic empowerment. The context in which women participate has the influence of formal organizations in society, which are systems of controlled and coordinated activities that arise from complex relationships and networks, which define rules according to the purpose of the institutions. The organization in modern society is very bureaucratic, first because as they modernize, they become more complex and second, modern society has goals to achieve. Participation in society has resulted from local leadership and organization, which is often seen as a deviation to achieving the goal, but we must consider that organizations adapt to the context (Meyer \& Rowan, 1977).

Researches emerges and broadens the discussion about women in areas such as economics, politics, and society, and this phenomenon cannot be considered unprecedented. It is a theme that draws attention to statistics, politics and social scientists. Women's participation and role in society has become increasingly active, with dynamic participation in various sectors, also impacting the labor market, where male and female participation has several gaps, which are most intense in developing economies. development (Carvalho \& Fernandes, 2018).

Entrepreneurship has an important contribution to the economy and according to Degen $(2009, \mathrm{p} .8)$ is "one who has the vision of the business and does not measure efforts to realize the venture. Its realization is to see your idea materialized in your business" and according to Mintzberg (2009) entrepreneurship, is an individual skill.

To answer the question access and use of technology and entrepreneurship as a strategic action can contribute to women's empowerment for the management of professional career in the area of executive secretariat? The hypothesis below was formulated:

H1 - Technology is a strategic tool that empowers a woman executive secretary to pursue a career or business. 


\section{METHODOLOGY}

With the purpose of producing knowledge about the change of executive secretarial service rendering using technology, applied research has a qualitative approach.

The research had an exploratory procedure, with theoretical foundation and relevant data on the performance of the Sindicato das Secretárias e Secretários do Estado de São Paulo-SINSESP. The research procedure includes collecting data on the performance of a group of secretaries through an in-depth interview by an entrepreneurial executive secretary, who sought to investigate information to understand the participant's point of view, considering observation and the wealth of ideas. The questionnaire complements the research to understand whether undertaking executive secretary service by offering a package of services to the private and individual is a phenomenon. The questionnaire was sent to the SINSESP database and collected information from the reality of a specific group, regarding the use of technology and the service offer, and then presented a deductive conclusion.

[...] Not all members of the population studied were surveyed. Rather, we selected, through statistical procedures, a significant sample of the entire universe, which is taken as the object of investigation. The conclusions obtained from this sample are projected for the entire universe, taking into account the margin of error, which is obtained through statistical calculations. (Gil, 2010, p. 35).

The survey link was emailed and was available from March 25 to April 27, 2019. The survey reached 128 respondents.

The questionnaire included questions that included the respondent's profile, the use of technology as a strategic tool, the contribution of using technology to women's empowerment, the contribution of using technology to executive secretary entrepreneurship, and the tendency of executive secretary in offering a package of services as an entrepreneur of her profession.

The questionnaire helped to understand current behavior to produce or generate applied strategies, according to the question:

How access to and use of technology and entrepreneurship as a strategic action can contribute to women's empowerment for career management in the area of executive secretariat. 4. Analysis and Results

As part of the descriptive procedure, the analysis of the collected data begins.

The first data collection was done through in-depth interviews with the company Click Secretária.

The sample was judged, due to access to company contacts, in addition to meeting some criteria that contribute to the research (Marshall, 1996). The company uses technology to provide executive secretarial services.

The company http://www.clicksecretaria.com.br/ was born in March 2018 with the proposal to offer a package of services for the remote executive secretary. The company is hosted on an online platform, making it easy to offer services, contacts and company visibility. The owner is 42 years old and has been working for 21 years as executive secretariat. Formed 1998 by the Universidade Bras Cubas, did internship in the same year at Ford do Brasil, in São Bernardo - Gerência de Vendas \& Marketing. In 1999, he had an opportunity at Metalpack do Brasil (after Cebal do Brasil, Alcan and currently ALBEIA) Executive Secretary - Plant Director. In 2005, she worked at Behr Brasil (currently Mahle Behr) - served as Secretary of Engineering, Production, Quality, conciliating attendance for up to 5 executives simultaneously with the support of an apprentice. In 2008 went to Ericsson do Brasil - initially as Legal Secretary and later for Human Resources - Operational, sequentially in January 2009 started activities for Valtra do Brasil (AGCO Máquinas Agrícolas) - Advising the Vice President of Sales and Marketing for South America, and its Sales Directorate Staff and respective management. In March 2018, after 20 years of training, working in the private sector, ended his period in the corporate and a few months later, after completing EMPRETEC, Sep / 2018 The time has come to undertake and found Click Secretária with Remote Service.

The career was built progressively, in which in the changes of companies added new functions, positions and always by choice, seeing personal and professional growth and professional experiences in other segments. The interviewee is fluent in the languages: English, Spanish, and studied for a few years French and German 
(these two basics due to lack of practice). He sought knowledge, in addition to Academic teaching, secretarial training and Post Graduation in Marketing, participated in Courses, Lectures, Forums, Congresses and Exchanges, with strong performance in large multinationals. It has several characteristics and acts as: Mother, Driver, Executive, Daughter, Friend, Entrepreneur \& Businesswoman, Counselor, Home Administrator, Acting in Voluntary Work, Adviser, Multitasking, Proactive, Anticipates Problems and Questions, Facilitator, Student, teacher, reinvents herself daily. In his 20-year career, he has seen a lot change, including: industrial revolution and technology, social networking, digital marketing, task time optimization, planning, market instability, new business models, emotional intelligence, and intergenerational culture clash. For your business model there are essential skills, including intrapersonal and interpersonal skills, creativity, collaboration and innovation.

The interviewee reports that the remote executive secretary is very recent in the country, and has been in the market for about 10 years. Unfamiliar statistics, the liberal professional fits with her region, her performance, her experience (ideal that is in constant networking and is a valued professional and that values the profession (training, experience $=$ adds value). Whether simple or elaborate, time demand drives the ultimate value of service (you're using your time for the executive, entrepreneur, liberal professional to focus on his or her business) without missing important meetings, follow-ups, being available when contacted. In terms of remuneration - the power will be in your hands, how many hours you will devote, what your discipline will be, your networking, your engagement and constant updating / recycling, as a showcase, your services will be for "purchase" either on time or in contracts. With fixed demand, it is important to determine the value of your working hours and to adjust with your fixed / variable costs for to make it viable and bring the desired returns. Undertaking is a challenge and for that you need to study, research, update, recycle and work, and whenever you need to reinvent and adjust (your work with the demands and needs / pains of your customers). The profile of the executive secretary in the past was once more a passive and operational role, but today she presents herself dynamically and actively, with business knowledge, team skills, emotional and multifaceted intelligence that follows a future of strategic action, whether in the initiative. privately and remotely.

The interviewee was always entrepreneurial, at the beginning of her career, she undertook teaching English (she was recognized by co-workers as a person who would do this role well, knowing the language, calm, patient and teaching characteristics) and together with a co-worker, which had the same recognition for just over two years moved the "Partners" (name that the partners used for the venture), working in one of the partners' house and had 4 classes and 12 students (always Saturdays and night hours). Aware that he was a differentiator in his career, he has always invested in knowledge and language courses. In their trajectory, people were instrumental in recognizing their determination and willingness to work.

Even when I was graduating in executive secretariat, at the beginning of the course in 1996, I heard about the end of the profession, but gradually some activities in companies started to be directed to the executive secretary, because the course covered notions of management, accounting, human resources, perpetuating the professional. The differential was the professional taking on other roles and activities, in the case of the interviewee, she took over and specialized in budget planning. From this knowledge of the financial area, companies began to treat the interviewee far beyond an executive secretary, but a partner employee who comes forward with problems and presents solutions.

The interviewee faces the challenge of motherhood, and the decision to undertake came due to the dismissal of the last company she worked for. She has been married for 5 years with an engineer working in a large multinational in strategic roles and her activities require many external trips, and with this temporary absence from home, the interviewee also does all the home management. After his resignation in March 2018, he sought new knowledge and preparation at SEBRAE and EMPRETEC, researched the current and future market of the executive secretary and decided to undertake, in September of the same year, already had his own company's CNPJ. The first clients came up and these were the executives he worked for in private companies.

The interviewee faced some challenges, tried to participate in networks and seek information with other women, but had difficulty integrating because of their own prejudice and also difficulty finding professionals with more experience or experience for exchanges and networking / benchmarking.

Currently, in his company, he is moving towards establishing a partnership with other professionals with remote enterprise providing services aligned to Click Secretaria. Despite being entrepreneurial, the interviewee emphasizes the importance of holidays and quality time, so she intends to grow by integrating other people in the offer of services, such as "package". The interviewee, when resolving to undertake, asked some questions that contributed the personal development plan to her career plan: How to keep working and monetize and get closer to my child? 
The second part of the data collection was through a questionnaire to understand if the professional executive secretary understands entrepreneurship as a career alternative. Of the 128 respondents, 120 are female, 4 are male and 5 did not identify themselves. The age of respondents is between 19 and 64 years old. The level of education is distributed as follows: undergraduate level with 50 respondents, 62 with postgraduate, 7 with master's degree and 5 did not report. Below is a table of income according to educational level and the increase in income according to education is noticeable.

Table 2. Income $\mathrm{x}$ Degree of Education

\begin{tabular}{|c|c|c|c|c|c|c|}
\hline Renda \Grau de escolaridade & Não informado & ensino medio & graduação & pós graduação & doutorado & Total Geral \\
\hline Não informado & 4 & & 1 & 2 & & 7 \\
\hline ate $2 \mathrm{mil}$ & & 2 & 15 & 2 & & 19 \\
\hline de $2.001,00$ a 4 mil & & 2 & 12 & 10 & & 24 \\
\hline de $4.001,00$ a 6 mil & & 1 & 11 & 19 & 2 & 33 \\
\hline de $6.001,00$ a $8 \mathrm{mil}$ & & & 1 & 13 & 2 & 16 \\
\hline acima de $8 \mathrm{mil}$ & & & 10 & 16 & 3 & 29 \\
\hline Total Geral & 5 & 5 & 50 & 62 & 7 & 128 \\
\hline
\end{tabular}

Source: authors

The data indicated that $89 \%$ of respondents believe that the executive secretary profession is in the process of changing. Technology enters the scenario as a strategic tool for adaptation in this process. About the possibility of the end of this profession, 67\% do not believe it can happen, and the others believe in adapting, updating, restructuring and offering the service remotely. Below, some relevant data found:

Female empowerment - $91 \%$ believe that the use of technology contributes to female empowerment.

Technology as a tool $-95 \%$ of respondents use technology as a work tool and $89 \%$ consider it as a strategic tool. $95 \%$ of respondents believe technology contributes to executive secretary entrepreneurship. This information confirms the hypothesis that technology is a strategic tool that empowers the female executive secretary to pursue a career or business, and addressed by authors Sirotin and Arkhipova (2018).

Entrepreneurship - $64 \%$ of respondents want to undertake, $30 \%$ have no interest and $6 \%$ could not answer. Of those who want to undertake, the areas that stand out are: $20 \%$ would like to undertake as secretary and remote advisory, $5 \%$ in consulting, $5 \%$ in training, $4 \%$ in fashion, $3 \%$ in beauty and $2 \%$ in education.

\section{CONCLUSION}

Entrepreneurship can be a strategic action for professional growth in the area of executive secretariat. Access to and use of technology contributes to women's empowerment in the executive secretariat area. Undertaking is a strategic action for career management both within private enterprise and to undertake one's own business.

Despite technological changes and strategic tools, the professional executive secretary is competitive and important within organizations because she has moved from an operational role to a participatory strategic role in decision making, with teams and information under her management. The digital and technological transformation made it possible to offer the service and the performance of the executive secretariat professional remotely, bringing benefits to the relationship with the companies that seek these services.

The political economic scenario presents a new behavior within organizations, in which the exclusive and individual service has been adapted to a team of secretaries that, besides attending to the executives, do other activities within the organizations. Another important factor is that many professionals are registered with different nomenclatures, such as assistant, assistant, receptionist secretary, among others. For the position, there are more than 500 nomenclatures for the secretary profession. And despite the undergraduate degree in executive secretariat, not all professionals have the record, because courses such as administration, economics, letters etc, allow the exercise of the profession.

The theoretical foundation contributes to the thinking of career development of the executive secretary and technology is presented as a tool for the empowerment of the professional. Data collection through the interview presents the possibility of undertaking one's own business, an opportunity that technology has provided. 


\section{REFERENCES}

Arul Paramanandam, D., \& Packirisamy, P. (2015). An empirical study on the impact of micro enterprises on women empowerment. Journal of Enterprising Communities: People and Places in the Global Economy, 9(4), 298-314.

Almeida, W. A. G. Competências dos Profissionais de Secretariado de Empresas Nacionais, Nacionais Internacionalizadas e Estrangeiras no Brasil - Dissertação apresentada como requisito para obtenção do título de Mestre em Administração, com concentração em Gestão Internacional, pela Escola Superior de Propaganda e Marketing - ESPM - São Paulo, 2016.

Brasil. Ministério da Educação. Conselho Nacional de Educação. Diretrizes curriculares nacionais para o curso de graduação em secretariado executivo.

Brasília. DOU 11 mar. 2004. Disponível em www.sinsesp.com.br. Acesso em 06 de fev. de 2019.

Brasil. Ministério do Trabalho e Emprego. Classificação brasileira de ocupações. Brasília. 2002. Disponível em http://www.mtecbo.gov.br/informacao.asp. Acesso em 6 de fev. de 2019.

Batliwala, S. (1997). What is female empowerment?.

Britto, F.; Wever, L. (2003). Empreendedores brasileiros: vivendo e aprendendo com grandes nomes. Rio de Janeiro: Campus.

Carvalho, L., \& Fernandes, A. (2019). Management style and innovation of females in gender-atypical businesses. International Journal of Entrepreneurship and Innovation Management, 23(4), 383-398.

Casson, M. (1979). Alternatives to the multinational enterprise. New York: Holmes \& Meier Publishers, 1979.

. The entrepreneur: an economic theory. Oxford: Martin Robertson, 1982.

Chaves, T. J. (2015) O papel das multinacionais no desenvolvimento de negócios com impacto social no brasil. Dissertação de Mestrado. Disponível em: http://www2.espm.br/sites/default/files/pagina/thiago_chaves.pdf. Acessado em $18 / 8 / 2015$

Degen, R. J. (2009). O Empreendedor. São Paulo: Pearson Prentice Hall.

Dolabela, F. (1999). O segredo de Luísa. São Paulo: Cultura Editores Associados.

Dornelas, J. C. A. (2001). Empreendedorismo: transformando ideias em negócios. Rio de Janeiro: Campus.

Drucker, P. (1993). Post-capitalist Society, ButterworthHeinemann. 1993.

Dimenstein, G. (1995). Bom senso é vítima do desemprego. Folha de São Paulo, São Paulo, 5 de mai. 1995. Coluna Mundo, p. 22.

FENASSEC- Federação Nacional das Secretárias e Secretários. Secretárias. Categoria diferenciada. Definição Legal. Reflexos na profissão de secretariado. Aspectos legais. [2004]. Disponível em www.fenassec.com.br/coluna consultor. Acesso em 6 de fev. de 2019.

As melhores secretárias do mundo são as brasileiras. [2002?]- ano provável. Disponível em www.fenassec.com.br/artigos. Acesso em 6 de fev. de 2019.

Foucault, M. (1994). Power: The essential works 3. London: Allen Lane.

Gil, A. C. (2010). Como elaborar projetos de pesquisa. 5. ed. São Paulo: Atlas.

Hafkin, N., \& Taggart, N. (2001). Gender, information technology, and developing countries: An analytic study (pp. 42-48). Office of Women in Development, Bureau for Global Programs, Field Support and Research, United States Agency for International Development.

Knight, F. (1933). Risk, uncertainty and profit. London: Houghton Mifflin.

Laudon, K. C.; Laudon, J. P. (2007). Sistemas de Informação Gerenciais. 7. ed. São Paulo: Pearson Prentice Hall.

Marinho, P. A. S., \& Gonçalves, H. S. (2016). Práticas de empoderamento feminino na América Latina. Revista de estudios sociales, (56), 80-90.

Marshall, M. N. (1996). Sampling for qualitative research. Family Practice. Oxford University Press.

Meyer, J. W.; Rowan, B. (1977). Institutionalized Organizations: Formal Structure as Myth and Ceremony. American Journal of Sociology, v. 83, n. 2, p. 340-363.

Mintzberg, H., Ahlstrand, B., \& Lampel, J. (2009). Safári da estratégia. Bookman Editora.

Neiva, E. G.; DElia, M. E. S. (2014). As novas competências do profissional de secretariado. 3. ed. São Paulo: IOB.

Sirotin, V.; Arkhipova, M. (2018). Gender Aspects in Using Digital Technologies by Population in Russia. International Conference on Gender Research (ICGR 2018). Porto, Portugal. 2018.

Schumpeter, J. (1950). Capitalism, socialism, and democracy. 3 ed. New York: Harper \& Row.

Weber, Max. (1991) Economia e Sociedade. Brasília: Editora da UnB. vol. 1, cap V (Sociologia da Religião).

Yin, R. (1984). Case study research: Design and methods. Newbury Park, CA: Sage. 